\title{
Medical discourse and municipal policy on prostitution: Palma 1862-1900
}

\section{Eva Canaleta Safont $\left(^{*}\right)$ y Joana Maria Pujades Móra (**)}

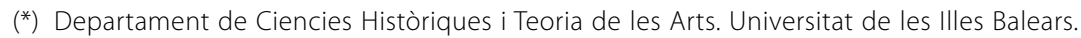
eva.canaleta@uib.es

$\left.{ }^{* *}\right)$ Departamento de Población. Instituto de Economía, Geografía y Demografía. CSIC. joanapujades@ieg.csic.es

Dynamis

[0211-9536] 2008; 28: 275-299
Fecha de recepción: 6 noviembre de 2007

Fecha de aceptación: 21 de enero de 2007

SUMMARY: 1.- Introduction. 2.- Stigma of syphilis and social exclusion of prostitutes. 3.-Medicine and prostitution-syphilis in Mallorca. 4.-The regulation of the prostitution: laws and general context. 5.-Municipal regulation of prostitution in Palma (19th Century). 6.-Final remarks.

ABSTRACT: During the 19th century, prostitution aroused strong emotions in most European cities. Palma de Mallorca was no exception and, in common with many Spanish cities at that time, regulated this activity. The objectives of this paper are to analyze the Mallorcan medical discourse on syphilis, evaluate the concept of venereal disease as social stigma and, finally, examine municipal policy on prostitution.

PALABRAS CLAVE: Prostitución, discurso médico, estigma, salud pública, organización municipal. KEYWORDS: Prostitution, medical discourse, stigma, public health, municipal organization.

\section{Introduction $(*)$}

Prostitution, as Evans ${ }^{1}$ indicates, is one of the distinguishing traits of nineteenth-century urban culture, because of its widespread nature as well as the obviousness with which it flaunted itself, a source of considerable

$\left({ }^{*}\right)$ This article was supported by predoctoral grants froms the Spanish Ministry of Education and Science, and the Balearic Islands Department of Economy and Innovation. The authors have contributed equally to this article.

1. Evans, Richard J. Prostitution, state and society in venereal Germany. Past and Present. 1976; 70: 106-129. 
alarm among contemporaries. Prostitution, syphilis and its regulation have been generating a great amount of literature among the medical historians $^{2}$. In Spain, prostitution aroused strong emotions in big cities such as Barcelona and Madrid, as well as in ports cities and those with major military detachments. Some of the Spanish hygienists considered the prostitution as a feature of civilizations: P. F. Monlau pointed out «Prostitution is an ulcer of the big populations» ${ }^{3}$, and the more disgusting, the more impure and the more putrid profession; Santero ${ }^{4}$ considered the more civilized society the more vices developed, specially the prostitution. For that reason it had to be regulated. Literature from the period refers to it and to venereal diseases as a «social disease», together with tuberculosis and alcoholism, and, as Castejón Bolea ${ }^{5}$ pointed out, venereal diseases became a metaphor for the definitive moral and physical decline of the social order. The contemporary physicians regarded ailments of the «social

2. Some of the more relevant examples are cited: Baldwin, Peter. Contagion and the state in Europe 1830-1930. Cambridge: Cambridge University Press; 1999. Bolet, Alfred J. Plagues and poxes: the impact of human history on epidemic disease. New York: Dmos; 2004. Crissey, John Thorne; Parish, Laurence Charles. The dermatology and syphilology of the nineteenth century. New York: Praeger; 1981. Davidson, Roger; Hall, Lesley. A. Sex, sin and suffering: veneral disease and European society since 1870. London-New York: Routledge; 2001. Davidson, Roger. Dangerous liaisons: a social history of venereal disease in twentieth-century Scotland, Amsterdam; Atlanta, GA: Rodopi; 2000. Davidson, Roger. Venereal disease, public health and social control: the Scottish experience in a comparative perspective. Dynamis. 1997; 17: 341 368. Harsin, J. Syphilis, wives and physicians: medical ethics and the family in the late 19th century France. French Historical Studies. 1989; 16: 72-95. Lomax, Elisabeth. Infantil syphilis as an example of the 19th century belief in the inheritance of acquired characteristics, Journal of the History of Medicine and Allied Sciences. 1979; 34 (1): 23-39. Martensen, Robert L. Syphilis, contagion and the place of sexuality in late 19th century America. JAMA. 1994; 272 (27): 269. Mccullum C. Disease and dirt: social dimensions of influenza, cholera and syphilis. Pharos and Alpha Omega Honor Medical Society. 1992; 55 (1): 22-29. Meyer, Gregg S. Criminal punishment for the transmission of the sexually transmitted diseases: lessons from syphilis. Bulletin of the History of Medicine. 1991; 65 (4): 549-564. Kertzer, David I. Syphilis, foundlings, and the wetnurses in 19th century Italy. Journal of Social History. 1999, 32 (3): 589-602.

3. Monlau, Pedro Felipe. Elementos de higiene pública o arte de conservar la salud de los pueblos. Madrid: Imprenta Rivadeneyra; 1862, p. 923.

4. Santero, Francisco Javier. Elementos de higiene privada y pública. Madrid: El Cosmos Editorial; 1885.

5. Castejón Bolea, Ramón. El discurso médico en torno a la prostitución. Historiar. Revista trimestral de historia. 1999; 2 (1): 52-61. 
body» prostitution, drunkenness, vagrancy and mendicancy, criminality and suicide ${ }^{6}$.

The aim of this article is to examine the relationship between syphilis and prostitution in Palma de Mallorca (Spain) from 1862, when provincial authorities drafted the first health regulations for prostitutes, to 1900. The study's objectives are basically twofold:

1. To analyse medical discourse in Mallorca on syphilis and prostitution and its relationship to the construction of the stigma of disease and social exclusion.

2. To evaluate the action taken by Palma's local authorities in the arena of hygiene and prostitution.

The sources consulted were the Mallorcan medical journal and local press, medical literature as well as administrative documentation ${ }^{7}$.

\section{Stigma of syphilis and social exclusion of prostitutes}

Discussing prostitution, especially during the second half of the nineteenth century, involves examining the prostitution-syphilis tandem and the effects of this association: the stigma of syphilis and the stigma or social exclusion of prostitutes. This article does not seek to describe the different theories on stigma, which have been extensively studied by sociology, anthropology, psychology and psychiatry, but rather to borrow the concept and apply it to History. Nevertheless, we believe it opportune to define our understanding of stigma and specify how it will be used here.

According to Reidpath ${ }^{8}$, defining «stigma» means delving into a host of meanings, ranging from the original idea of a «mark» to abstract notions of stereotypes, rejection and social distance. Goffman contends that a stigma is a mark that devalues an individual as a whole:

6. Santero, n. 4, p. 487.

7. Revista Balear de Ciencias Médicas (1885-1900), the Colegio Médico-Farmaceútico de Palma (Mallorcan Medical-Pharmaceutical Association) official journal. First published as Revista Balear de Medicina, Farmacia y Veterinaria. The local press: El Isleño (1873-1885) and La Almudaina (1885-1900). Administrative documentation from the Palma Town Hall and the Provincial Government.

8. Reidpath, Daniel D. et al. «He hath the French Pox»: stigma, social value and social exclusion. Sociology of Health and IIIness. 2005; 27 (4): 468-489. 
"[arising] during social interaction, when the social identity of an individual is found to be "spoiled" by attributes that mark him or her as deviant (from the group norm) and as being incapable of fulfilling the role requirements of that or other social interactions» 9 .

Hence, stigmatisation is the process that determines which individuals or groups will be «insiders» or «outsiders». Prostitution is illustrative of that mechanism in the case in hand. Therefore, we consider two aspects of stigma:

1. As a «mark of disgrace», the result of suffering syphilis. This mark is demonstrated both in the disease's symptoms and physical manifestations as well as in the repercussions on the sufferer, for example, discrimination by medical services. In addition, as a «mark of shame», the result of being entered in a registry.

2. As a mechanism of social exclusion and creator of identities. Fabrega Jr. expresses this clearly in the following sentence: «The poor, the sick, the deprived, and the marginal -including the mad- are said to constitute the group against which the majority developed its own identity» ${ }^{10}$.

This aspect is related to the idea of the disease as an individual sin and as punishment for transgression, yet the discovery of so-called «innocent victims» (basically children and married women) divided sufferers into «guilty» or «innocent» victims, in other words, into the groups that were inside or outside the norm. Gilman remarks:

«The fear of being marked as "unclean" through the means usually associated with "love" and "reproduction" made syphilis the most stigmatising disease in Europe and its colonies for almost 500 years. Only when the origin of syphilis was identified in the late 19th century and a specific cure for it developed in the 1940s, did the anxiety associated with this disease and its resulting trauma abate» ${ }^{11}$.

9. Goffman, Erving. Stigma: Notes on the management of spoiled identity, 1963, cited by Reidpath et al., n. 8, p. 470.

10. Fabrega, Horacio Jr. The culture and history of psychiatric stigma in early modern and modern Western societies: A review of recent literature. Comprehensive Psychiatry. 1999; 32 (2): 97119 (p. 109).

11. Gilman, Sander L. Disease and stigma. The Lancet. 2000, 354. 
According to the same author, throughout history, western society has identified transgressions from sexual norms, pollution, contamination and taboos with basically three diseases: leprosy, syphilis and now AIDS ${ }^{12}$. Leprosy stopped being endemic in Europe in the sixteenth century, but its symbolism continued in place until syphilis replaced it. Thus, syphilis, like AIDS today, are diseases that have been catalogued as «sexually transmitted diseases», although that is not always true. If we refer to Lluís Mallart's definition of the disease as something «that allows men to explain the different kinds of disorder that are capable of destabilising a society (...) disease is a medium through which men ponder society, organise it and restructure it» ${ }^{13}$ and especially the Evuzok worldview of the origin of the disease that it is attributed to endogenous causes, i.e., to the breach of a tribal law by one of its members; and to exogenous causes associated directly with witchcraft from the coast, since the Evuzok are an inland tribe, these ideas can be extrapolated to western history. Cataloguing syphilis and AIDS as STDs allows «the other» to be the origin of the disease. In his iconographic analysis of diseases, Gilman shows how the earliest depictions of syphilis allude to foreigners; in fact, the terminology referring to syphilis is an example of it: the French pox, the Neapolitan disease; the English accused the Catholics ${ }^{14}$. But the "other» is not necessarily a foreigner and from the Enlightenment on, women, especially prostitutes, were depicted as the source of infection:

«(...) by the 19th century «vice» becomes «disease», seduction becomes infection, the movement here is to continue the tradition of depicting the sufferer of a sexually transmitted disease as the outsider (initially the foppish or the French male), the sexual deviant. The female is seen as the source of pollution, but also as the outsider, the prostitute, the socially deviant individual» ${ }^{15}$.

12. Gilman, Sander L. Disease and representation. Images of Illness from Madness to AIDS. London: Cornell V.P; 1988.

Gilman, Sander L. Picturing health and illness. Images of Identity and Difference. Baltimore: The Hopkins University Press; 1995.

13. Quoted by Guasch Andreu, Oscar. La construcción médica de un estigma. Luego. 1989; 16-17: 87-99 (p. 87).

14. Siena, Kevin P. Pollution, promiscuity, and the pox: English venereology and the Early Modern Medical discourse on social and the sexual danger. Journal of the History of Sexuality. 1998; 8 (4): 553-574.

15. Gilman, Sander L. Disease and representation. Images of illness from madness to AIDS. London: Cornell V.P; 1988, p. 256. 
In any case, all throughout history, men have always been the victims rather than the source of the disease, proof of which was the debate between those in favour of regulating prostitution and those who would abolish it in the nineteenth and twentieth centuries.

\section{Medicine and prostitution-syphilis in Mallorca}

Fernando Weyler's Topografía Físico-Médica de las Islas Baleares y en particular de la de Mallorca was published in 1854 and in the "Antropological» section entitled Pasiones e Inclinaciones, he describes prostitution as follows:

«Prostitution is perhaps growing, but in general, it lives hidden under a cloak that conceals its forms. There is prostitution in the capital and the largest towns, but in both places, almost all the women who exercise such a disgusting trade come from the heart of countryside; peasant women are the ones who normally fuel such a repugnant plague, the opposite of what happens in other places, where almost all prostitutes come from the working classes.

Poverty does not force them to prostitute themselves, perhaps their little love for working, because jobs are not lacking for hard-working women and every year several offences against public morals figure in last place in the criminal statistics» ${ }^{16}$.

In his work La ciudad de Palma, Archduke Louis Salvador referred to prostitution in Mallorca in the following words, from which the veil of secrecy that shrouded this occupation can also be inferred:

«Prostitution and concubinage can also be found in Mallorca, but is generally maintained within discreet limits, if not in the utmost secrecy, and even in Palma, a port city, it is much less obvious than in other cities on the Spanish mainland» 17 .

16. Weyler y Laviña, Fernando. Topografía Físico-Médica de las Islas Baleares y en particular de la de Mallorca. Mallorca: El Tall; 1854, p. 137-138 (our translation).

17. Quoted by Rosselló Vaquer, R.; Bover Pujol, J. El sexe a Mallorca: notes històriques, II. Mallorca: Miquel Font, 1994, p. 214 (our translation). 
One of this paper's aims is to analyse Mallorcan medical discourse on prostitution and venereal diseases, especially syphilis. Unfortunately, albeit very significantly, we encountered very few documentary sources. As indicated in the Introduction section, we have culled a documentary data collection from the Revista Balear de Ciencias Médicas the monthly publication of the Colegio Médico-Farmaceútico de Palma (Mallorcan Medical-Pharmaceutical Association), which was founded in $1882^{18}$.

Six articles on syphilis were published from 1885 to 1887 , half of which were authored by Mallorcans. During these three years, M. H. Leloir's Lecciones sobre la sifilis, translated from the French publication Le Progrés Médical were published ${ }^{19}$. In the first lesson, the author questions individual freedoms (in France) and a syphilis sufferer's responsibility to his fellow citizens. Leloir finds an example to illustrate this issue in Norway where syphilitic men or women of «bad repute» were forcibly hospitalised, according to the author of the text. If a person infected by a recurrent syphilitic man or woman reported this to the police, the source could be jailed for a period of between three and six months. The crime of venereal contagion was not made a criminal offence under Spanish law until $1928^{20}$.

The disease's negative connotations and moral implications can also be surmised from the first lesson. The doctor who authored the treatise asserted in the Means of Contaminations (sic) section:

«1. Either (and this is the most frequent case) there is direct contact between the contaminant and the person who is then contaminated; this is the direct or immediate contamination (and not contagion, as some authors erroneously say), which is caused by coitus» ${ }^{21}$.

18. The journal itself was first published in 1885 and all the issues published until 1900 were analysed. The use of other documents from Spain, although not specifically from Mallorca, complements the analysis.

19. The first lesson was published on the Revista Balear de Medicina, Farmacia y Veterinaria, 1885, 1 (10).

20. Castejón Bolea, Ramón. El delito de contagio venéreo: la penalización como instrumento jurídico de la lucha antivenérea. In Montiel, Luis; Porras, Isabel, eds. De la responsabilidad individual a la culpabilización de la víctima. El papel del paciente en la prevención de la enfermedad. Madrid: Doce Calles; 1997, p. 203-218.

21. Revista Balear de Medicina, Farmacia y Veterinaria, 1885, 1 (24), p. 650 (our translation). 
The relationship between pure and impure as well as the idea of contamination appears in the same paper in allusion to the practice carried out by the «lower classes» (sic) of having sexual relationships with virgins of both sexes in the belief that the disease would go away through the contact. This idea was also decried by Spanish doctors: Juan Marsillach , who was in charge of visiting venereal patients at the Hospital de Santa Creu in Barcelona and who turned down the post of medical hygienist because he disagreed with regulating prostitution, wrote in relation to the care of private hygiene:

«We will also mention, although only to energetically condemn them for their uselessness and criminality at the same time, the practice of certain libertines of attacking children who have not reached puberty to infect them with the gonorrhoea they suffer from, in the belief or pretending to believe that they would be free or cured of their disease in this way» ${ }^{22}$.

In a footnote, the author mentions a case in which he had to intervene that involved a sixty-year-old woman who had molested an eight-year-old child.

Most of the articles published between 1888 and 1900 were translated from French. Some were included in special sections entitled Revista de Sifiliografía, specifically in 1889, 1896 and 1898. The remaining articles on syphilis did not belong to any concrete section in particular and appeared in the Medical Notes section as well as the Scientific or Miscellaneous Notes section $^{23}$. As for Mallorcan or Spanish authorship, we can only point to the publication of four articles on treating syphilis with hydromineral medication signed by Bernardo Leza and the above-mentioned bibliographies of two studies on syphilis and prostitution by Dr. Zabala, although the titles of the works are not referred to.

Finally, a note on syphilis cases in Mallorca was read at the Colegio Medico- Farmaceútico de Palma by José Ogazón on March 20, $1900^{24}$. The

22. Marsillach y Parera, Juan. ¿Qué medios deberá aconsejar el médico higienista al gobierno para atenuar los funestos efectos ocasionados por la prostitución? Memoria que en el ejercicio para el grado de Doctor en Medicina y Cirugía leyó el día 1 de julio de 1869. Barcelona: Jaime Jesús Roviralta, p. 26 (our translation).

23. The Revista Balear de Ciencias Médicas did not have set sections during the period studied.

24. Ogazón Cirer, J. Tres casos de sífilis. Nota leída el 20 de marzo del actual en el Colegio. Revista Balear de Ciencias Médicas. 1900; 18 (18): 409-413. 
first case involved a sailor with «syphilis simulating malaria» (sic) and the second a woman infected by a foundling. In both cases, two very clear ideas emerge in the conclusion of the doctor's note about venereal diseases and syphilis in particular. The first is the shame in admitting to syphilis because of the stigma involved. Ogazón mentions that the sailor «ended up confessing that he had had a chancre and gummata that did not suppurate some years before» ${ }^{25}$. The doctor laments «(...) of the few instances in which a sufferer confesses to his illness, sometimes owing to ignorance and sometimes owing to an incomprehensible obstinacy» ${ }^{26}$. This «incomprehensible obstinacy» to admit to a syphilitic disease is closely related to the collective imagery of the disease's origins (the transgression of the sexual norm and sin) and the punishment involved, which not only materialised in the stigma, but also in practical questions such as the treatment provided by professionals to cure it or their neglect. Again, Marsillach echoes this issue and in his advice to the government and suggests: «founding venereal hospitals or establishing special infirmaries for these sufferers in general hospitals, and providing good treatment, so that it will attract them instead of chasing them away» ${ }^{27}$. At this point, Marsillach expresses his disagreement with religious staff in hospitals as «people with an excess of religious fervour look askance, if not with horror, at those who contract illnesses through $\sin { }^{28}$. This relationship between syphilis and sin continued well into the twentieth century, as can be seen from in the following text ${ }^{29}$ which, like Marsillach, appeals to doctors' and health staff's sense of responsibility:

«The State (...) has decreed the mandatory treating of luetics since they pose a problem for other people's health (...). On the other hand, there have been and still are many villains in the health professions who, considering the sufferers to be vicious sinners, people who voluntarily acquired their illness, have denied them bread and water, have excluded them from assistance in societies, surgeries and even from entering hospitals. And in the face of the sufferer's sin, how many other sins did they commit, such as the lack of charity and not loving one's neighbour as oneself».

\footnotetext{
25. Ogazón, n. 24, p. 411 (our translation).

26. Ogazón, n. 24, p. 412 (our translation).

27. Marsillach, n. 22, p. 27 (our translation).

28. Marsillach, n. 22, p. 28 (our translation).

29. Álvarez Sainz de Aja, Enrique. Lo que todo el mundo debe saber sobre la sífilis. Folleto de divulgación. Madrid: Ministerio de Gobernación-Dirección General de Sanidad; 1946, p. 18-19 (our translation).
} 
As Reidpath et al. observe, the relationship between stigma, health and social exclusion is demonstrated in several ways: in the negative repercussions on the stigmatised individual's or group's health and in the discrimination they might have to contend with or even self-discrimination ${ }^{30}$.

The second idea, which is related to the above, is the syphilis-quack medicine duo. In both cases mentioned by Dr Ogazón, his patients were being treated by «a well-known quack» ${ }^{31}$. Marsillach considered it the government's responsibility, "obliged as it is to care for the health of those in its care» ${ }^{32}$ to dissipate the errors and concerns about curing venereal diseases, prohibit the sale of secret remedies and pursue quacks and charlatans. Marsillach takes the administration to task about secret remedies and advertisements for wonder cures and urges the authorities to ban them and persecute the charlatans ${ }^{33}$. That same concern can be seen in Rosselló i Olivés 1883 doctrinal treatise, in which the author emphasises the number of venereal sufferers in Barcelona who were not accounted for:

«Add (...) those who come to special surgeries, those who are visited in their homes and especially the horrifying number of those under the care of quacks and charlatans, those who self-medicate, and to do so make use of the means provided to them by friends or acquaintances who believe that because they themselves had been infected previously they know enough, and the not inconsiderable number of people who let themselves be seduced by pompous advertisements that newspaper are allowed to print and that are sold everywhere» ${ }^{34}$.

As in other places in Spain, the local Mallorcan press printed these secret remedies in its pages. Advertisements for French products that mention French doctors and medical schools in several cities appeared in El Isleño (1873-1885) and La Almudaina (1885-1900). Most of the advertisements

30. Reidpath et al., n. 8, p. 469.

31. Ogazón, n. 24, p. 412 (our translation).

32. Marsillach, n. 22, p. 27 (our translation).

33. Marsillach, n. 22, p. 27 (our translation).

34. Rosselló y Olivé, Ramón. La sífilis y la prostitución; sus relaciones; medios de prevenir sus perniciosos efectos. Discurso doctrinal, Acta de la sesión pública inaugural que la Real Academia de Medicina y Cirugía de Barcelona celebró el 30 de enero de 1883. Barcelona: Jaime Jesús, 1183, p. 65 (our translation). 
were for products with a wide range of applications; the word syphilis rarely appeared in the advertisements. Others announce explicitly that they are for secret or sexual diseases (plant depuratives without mercury, injections for men, vaginal douches and pills). Many announce that mercury is not an ingredient, a significant piece of information, taking into account the bad reputation it had justly acquired because of its side effects ${ }^{35}$.

A striking fact is that none of the summaries of the historical studies that the Colegio Médico-Farmaceútico de Palma had conducted since its foundation in 1882, which were published in the journal Revista Balear de Ciencias Médicas, dealt with syphilis or venereal diseases.

From the start, the Revista Balear de Ciencias Médicas published demographic health statistics on movements in the capital city's population. In the deaths section, syphilis appears as a cause of death by infectiouscontagious disease. Only five deaths from syphilis were reported in 15 years, specifically in 1887 (1), 1890 (2), 1893 (1) and 1897 (1), out of a population of approximately 60,000 inhabitants. These numbers just report the deaths for syphilis in the adult population, concealing the deaths for syphilis in the population from the charity institutions, like the foundling hospital. So, in this institution between 1881 and 1920 we have noticed 23 deaths for syphilis, almost for congenital syphilis. Probably syphilis in this kind of institutions was not a stigma; it was just the result of transgression ${ }^{36}$.

This data contrasts with data compiled by Fernando Weyler on Mallorca's medical topography, which echoes the large numbers of venereal patients in Palma's hospitals. Specifically, the number of venereal disease patients rose to 1449 in the period between 1847 and 1854 and scabies sufferers accounted for a total of 1055. In the section of his topography entitled Consideraciones sobre otras enfermedades, Weyler refers to venereal diseases as follows:

35. As examples, we describe some of the remedies that could be applied to venereal diseases: Ungüento Holloway: advertised as a remedy that «refrigerates and cleans all ill parts and cures sores and ulcers of all kinds». Jarabe Antiherpetico Palma: the only remedy in which the word syphilis appears in 1873. Like the others, it claims that mercury is not an ingredient. Zarzaparilla de Bristol: advertised in 1873 as a cure for scrofula, chronic sores, ulcers and humoral ailments, among others. It explicitly includes syphilis in 1885. Bob Boyueu Laffecteur: advertised specifically for new, chronic or mercury-resistant contagious diseases.

36. Pujades Móra, Joana Maria. The infant and child mortality transition in Palma (Mallorca), 1836-1960, Ph. D dissertation, in progress. 
«In special illnesses, there is a very interesting part, which is syphilis (cursive type in the original). This very widespread ailment is presented with all of its known symptoms. Syphilis patients are represented in exaggerated proportions compared with surgery patients in our hospital» ${ }^{37}$.

But syphilis was not the only illness that stemmed from prostitution and Marsillach, like Weyler above, pointed out that scabies was the second-most common illness after syphilis although, possibly because its origin could be accurately pinpointed, it did not bear the latter's stigma. Marsillach ${ }^{38}$ urged the government to popularise hygiene measures as well as «different antipsoric creams and pomades to kill the scabies bug».

As previously mentioned, the importance of syphilis compliments and transcends prostitution and therefore the implications of the disease should be linked to the value of «work» and eugenics.

These concerns are clearly illustrated in a manual entitled Divulgaciones Higiénicas. El sagrario de la salud ${ }^{39}$, a collection of essays written by Mallorcan physician Pedro Ferrer over the course of his career. This publication was an homage to Ferrer's 50 years of experience in medicine ${ }^{40}$ the title of which is already illustrative of its author's depiction of health and disease, consists of 38 chapters and a final section entitled Lecciones de rudimentarias nociones de higiene which sets out the Los diez mandamientos de la salud (Ten Commandments of Health) The topic considered in this paper was dealt with in the following chapters: Important advice for candidates for marriage (chapter 30); The law of inheritance (chapter 31); Human selection or eugenics (chapter 32); The very serious error (chapter 34).

Chapter 30 begins with the reproduction of a speech from the Netherlands on prenuptial propaganda which covers several pages:

37. Weyler y Laviña, n. 16, p. 251. It must be borne in mind that Weyler was a military physician and surgeon (our translation).

38. Marsillach, n. 22, p. 22 (our translation).

39. Ferrer, Pere. Divulgaciones higiénicas. El sagrario de la salud. Andraitx: Tipografía Calafell; 1930.

40. Although this date lies outside this paper's chronological timeline, the publication illustrates medical discourse on the disease. As the prologue states, Ferrer was born in Andraitx, Mallorca in 1855 and studied medicine in Barcelona. He practised medicine in his native town from 1879 onwards and occupied the post of Exterior and Municipal Health Inspector. 
«A healthy body with a healthy spirit contains the capacity and love for work. Moral and physical strength emanate from a healthy body, an important factor in marital and family well-being» ${ }^{41}$.

The doctor advocates the need for future wives to undergo medical examinations as:

«We are mindful that there may be some cases in which future spouses suffer a disease that they themselves do not know about and that a doctor is the only person who can describe these secret diseases, which of course imply delaying marriage for a more or less lengthy period of time» ${ }^{42}$.

Although the word syphilis does not appear in this chapter, no doubt can be entertained that its euphemisms or omissions directly refer to it. Chapter 31 is proof of that and of the moral dimension this disease had for the author of the work in reference. He begins by saying:

«With all certainty, it can be asserted that the venereal-syphilitic disease of the father, although he may have been considered cured, is prejudicial to the formation and development of the embryo. This is the law of inheritance, the hereditary sin, the fulfilment of that biblical punishment: the sins of the fathers shall be visited on the sons to the third or fourth generation» ${ }^{43}$.

The author's position on the Christian values of family, wife and descendants is clear. We reproduce a rather long, yet very instructive and illustrative paragraph on the author's ideas:

«A young German writer, Hans Wegener, is quite correct when he says that if whipping could be applied on occasion, it would be the punishment he would apply to the young and not so young people who commit the infamy, the brutality of marrying in the knowledge that they are suffering from the illnesses that should be called, not secret, but rather shameful. Yes, those curs, for whom the life and health of a woman is not enough to tear an honourable confession from their breasts, deserve to be publicly whipped. So, are we then protecting animals against all sorts of contagions and must

41. Ferrer, n. 39, p. 155 (our translation).

42. Ferrer, n. 39, p. 157 (our translation).

43. Ferrer, n. 39, p. 161 (our translation). 
we leave unhappy, defenceless women exposed to the horrible poison of venereal-syphilitic diseases?» ${ }^{44}$.

Ferrer explicitly mentions prostitution in this chapter and declares his total opposition to its regulation. He offers advice on what fathers' roles in educating their daughters should be and asserts that fathers should demand that suitors' undergo a medical examination and give their word of honour about their health: «No, no father who truly loves his daughter can consent that her blood, for any reason or under any circumstances, be corrupted by a vile and shameless vice» ${ }^{45}$.

Prostitution was regulated in Palma for the first time in 1862, although we do not have access to these regulations. We infer that the pro-regulation posture was not the prevailing attitude among the authorities in Palma from a text that dates to 1863 . This text ${ }^{46}$ reflects the concerns about syphilis, which it describes as «the most repugnant of illnesses and one which drags (young people's) spirit to the most deplorable moral degradation», with the aggravating circumstance of transcending the generation that contracts it. Nevertheless, the most interesting part of this document consists of two interrelated questions. The members of the Town Council believed the «provisions worthy of being approved», but considered that several issues should be pondered because of the serious drawbacks that would arise from their application. The first point consisted in whom and on the basis of what criteria the women or prostitutes who are to be registered would be defined; the Council posed the following question that expressed their concern for privacy:

«How to enter in the sanctuary of private life, making a repugnant inquisition to determine whether a woman has prostituted herself to such a degree that she must be entered in the register?» ${ }^{47}$.

\footnotetext{
44. Ferrer, n. 35, p. 162 (our translation).

45. Ferrer, n. 35, p. 163 (our translation).

46. Dictamen del Consejo Provincial acerca de la inconveniencia de reglamentar las putas de Palma del modo que propone el gobernador político Marqués de Ullagares, 10 de Enero de 1863. In: Vaquer, Onofre. La sexualitat a Mallorca: documents històrics. Palma de Mallorca: Obrador del Llibre; 1987, p. 51.

47. Dictamen, n. 46, p. 51 (our translation).
} 
The register, furthermore, which was the symbol and generator of the stigma of shame mentioned above and the Town Council understood it as «that repugnant humiliation, that mark of shame stamped on the foreheads of those who are registered and subject to recognition» ${ }^{48}$. The Council showed a special sensitivity to Mallorcan peculiarities when it warned the Governor about applying this ordnance:

«in a land ${ }^{49}$ where population movement is null and under these circumstances, the most insignificant facts acquire greater proportions than in cities on the continent, a land where everyone knows each other and where God-fearing consciences easily revolt at the least thought of regulating anything that religion and morality disapprove of $(\ldots)$ in the regulation project that Your Excellency has submitted for examination, there are extremes that the laws, morality, opinions and customs of this well-behaved land condemn» ${ }^{50}$.

\section{The regulation of the prostitution: laws and general context}

The regulation of prostitution in Spain in the nineteenth century was part of a wide-ranging project conducted in the name of public hygiene, prompted by the century's recurring epidemic crises, especially cholera ${ }^{51}$. It existed two kind of discourses in the conception of prostitution, one was the regulation of that and the other was the abolishment. But the first was the prominent option during the nineteenth century and the third decade of the twentieth century in Spain and also in Mallorca. Many provincial capitals, especially port cities, regulated the prostitution from the second half of the nineteenth century onwards. The tacit justification of this service, as Guereña pointed out, was determined by:

\footnotetext{
48. Dictamen, n. 46, p. 51 (our translation).

49. The word «land» was used here, in nineteenth-century fashion, to refer to the local setting, i.e., Mallorca, and not to Spain as a whole.

50. Dictamen, n. 46, p. 51 (our translation).

51. Guereña, Jean-Louis. El tiempo de la prostitución reglamentada. Madrid (1847-1909). In: El Trabajo de las mujeres: pasado y presente. Actas del Congreso Internaciona del Seminario de Estudios Interdisciplinares de la mujer. Vol 2, Málaga: Diputación Provincial; 1996. p. 5375. And, Guereña, Jean-Louis. Prostitución, estado y sociedad en España. La reglamentación bajo la monarquía de Isabel II. Asclepio. 1997; 49 (2): 101-132.
} 
«Police (eradicate potential elements of social disorder) and especially medical aspects (growing concern of hygienists in the face of the great fear of venereal diseases) [...] And the result meant a strategic compromise between the Family and the State, in a society of social discipline and vigilance» ${ }^{52}$.

Although these words perfectly and very synthetically depict the process that led to regulation, the specific points that accompanied the start and development of local (provincial/municipal) provisions on prostitution in the city of Palma, capital of the province of the Balearic Islands, are worth examining.

A second aim of this paper is to represent the city's organisation of the prostitution hygiene service ${ }^{53}$. Nevertheless, the manner in which the hygiene area of public health was handled in nineteenth-century Spain must be understood in order to evaluate the regulation process prostitution was subjected to in the second half of the century. The scope of municipal powers in the area of ordinary public health in the nineteenth century was restricted to maintaining local health and hygiene. For example, and especially illustrative of the first half of the century, the first article was the result of the notion set out in the Constitución of 1812 of an incipient municipalisation in dealing with public health:

«As town halls are responsible for policing health and comfort, they must oversee the cleaning of the streets, markets, public plazas and hospitals, jails and charity homes; safeguard the quality of all kinds of foods; ensure that each town has a conveniently located cemetery; also oversee the desiccation or diverting of stagnating or unhealthy waters and lastly, deal

52. Guereña, n. 51, p. 53 (our translation).

53. There is a great amount of literature about the Spanish public regulation. Alcaide González, Rafael. La higiene de la prostitución en Barcelona: una aproximación a los contenidos medico-sociales del higienismo en España durante el siglo XIX. GeoCritica [publicación seriada en internet]. 2000 [citado 5 Abril 2006]. Disponible en: www.ub.es/geocrit/pspestin. htm. Castejón Bolea, Ramón. Las enfermedades venéreas y la regulación de la sexualidad en la España contemporánea. Asclepio. 2004; 56 (2): 223-241. Castejón Bolea, Ramón. Moral sexual y enfermedad: la medicina española frente al peligro venéreo (1868-1936). Granada: Universidad de Granada; 2001. Guereña, Jean-Louis. La prostitución en la España Contemporánea. Madrid: Marcial Pons, Ediciones de Historia S.A.; 2003. Guereña, JeanLouis. De Historia Prostitutionis. La prostitución en la España contemporánea. Ayer. 1997; 25: $37-72$. 
with everything that may alter public health or that the health of livestock in the town or district» ${ }^{54}$.

Thus, in terms of ordinary municipal public health, prostitution hygiene was not one of its hobbyhorses. A prostitution hygiene service would not be organised until the mid-nineteenth century, when several provincial capitals individually took advantage of provincial discretionary powers to do so.

Public hygiene was basically the fundamental factor in safeguarding public health in cities and especially in preventing the effects of epidemic diseases (mainly cholera and yellow fever) and permanent endemic diseases (smallpox, typhus, diphtheria, scarlet fever, etc.) ${ }^{55}$. Therefore, when considering the influence of the surroundings and the social framework of diseases, the structure of cities and epidemics were the prefect combination for making health measures the main weapons in the struggle against epidemics and the key to medicalising society. Regulating prostitution could be found under the «Special Hygiene» section heading and considered just another hygiene concern. In contrast to the approach to epidemics, which was based on a homogenous nationwide structure, although a rather tardy one in relation to the first cholera epidemic in Spain (1833-35) ${ }^{56}$,

54. Artículo I: Instrucción para el gobierno económico y político de las provincias de 13 de junio de 1813 (our translation).

55. Urteaga González, Luís. Miseria, miasmas y microbios. Las topografías médicas y el estudio del medio ambiente en el siglo XIX. Geocrítica [publicación seriada en Internet]. 1980 [citado 5 Abril 2006]; 29. Disponible en: http://www.ub.es/geocrit/geo29.htm. Concerning the history of Public Health in the Spain of 19th century and the beginning of the twenties, see: Rodríguez Ocaña, Esteban. El movimiento higienista en la España urbana del siglo XIX ¿utopía o contradicción? Eidon Revista de la Fundación de Ciencias de la Salud. 2006; 20: 57-62. Rodríguez Ocaña, Esteban. Salud Pública en España: Ciencia, profesión, política, siglos XVIII-XX. Granada: Editorial Universidad de Granada; 2005. Rodríguez Ocaña, Esteban. Los servicios de salud pública en la España contemporánea. Trabajo Social y Salud. 2002, 43: 91-116. Rodríguez Ocaña, Esteban. La Salud pública en la España de la primera mitad del siglo XX. In: Atenza, Juan; Martínez, José, eds. El Centro Secundario de Higiene rural de Talavera de la Reina y la sanidad española de su tiempo. Toledo: Junta de Comunidades de Castilla la Mancha; 2001. p. 21-42 and Marset Campos, Pedro; Rodríguez Ocaña, Esteban; Sáez Gómez, José Manuel. La Salud Pública en España. In: Martínez Navarro, Ferrán et al. Salud Pública. Madrid: MacGraw-Hill Interamericana; 1998. p. 25-47. And in order to understand the relationship between hygiene and moral, see: Campos Marin, Ricardo. La sociedad enferma: Higiene y Moral en la España en la segunda mitad del siglo XIX y principios del siglo XX. Hispania. 1995; 55 (191): 1093-1112.

56. Rodríguez Ocaña, Esteban. Enfermedad y sociedad en la Andalucía del siglo XIX. La epidemia de cólera de 1833-1835. Granada: Secretariado de Publicaciones de la Universidad de Granada; 1981. 
prostitution hygiene began as an individual concern in several of Spain's capital cities in the mid-nineteenth century and was driven by provincial initiative, i.e., all the regulations and administration were handled at this level. The spread of this type of service, which meant its municipalisation at the same time, would not be a reality until the 1880's, a time of clear struggle to secure power over the governance of public health. Spanish municipalities claimed the power to regulate and administrate the system under the provisions of the Ley Municipal of 1870. Section 72 of this Ley Municipal envisaged that:

«It is the exclusive domain of town halls to govern and direct interests peculiar to the towns under num 1 of Art. 84 of the Constitution, and in particular those related to the following objects: $1^{\circ}[\ldots] 7$. Proceedings for health services and instruction $[\ldots] 2^{\circ}$. Rural and urban police or anything related to proper order and supervision of the established municipal services; overseeing public spaces in general and cleanliness, health and hygiene in the town» (our translation).

Therefore, the definition of municipal public health had not changed very much since the inception of Spanish liberalism; the difference lay in that, as of the second half of the nineteenth century, municipalities viewed the need to administrate the prostitution hygiene service as an additional part of their own hygiene project.

Thus, in late 1881, the Palma Town Council, under Section 72, agreed to organise this service by appointing a special commission made up of five members ${ }^{57}$. The Provincial Government annulled this agreement, arguing that it meant the usurpation of its authority in matters of public order ${ }^{58}$. At the same time, it must be understood as the loss of a service that had existed since the 1860's and had provided economic income for provincial budgets. Thus,

"[...] in Madrid, as in provincial capitals, with the exception of the years between 1889 and 1892, years that were beyond their control, civil govern-

57. Commissioners Marroig and Escafi petitioned the Town Council to constitute a commission to establish and create municipal services for neighbourhood hygiene, which included prostitution hygiene. Petition by these commissioners to the Town Council of 07/12/1881. Higiene de la Prostitución. Archivo Municipal de Palma, Fons Pons i Fàbregues, 1126/V.

58. Oficio del Ayuntamiento de Palma al Gobierno de la Provincia, 25/02/1882. Higiene de la Prostitución. Archivo Municipal de Palma, Fons Pons i Fàbregues, 1126/V. 
ments organised this service more on the basis of discretional powers than according to powers recognised by provincial laws» ${ }^{59}$.

The Palma Town Council's agreement was definitively annulled, although the provincial ruling was appealed before the Minister of Governmental Affairs ${ }^{60}$. No response was forthcoming until early 1889 , when the Minister of Governmental Affairs issued a Royal Order that decreed:

«That of course hygiene services in Provincial Governments for brothels or any other type and the registration and issuing of medical cards to (sic) persons who devote themselves to domestic service is hereby suppressed» ${ }^{61}$.

Justifying this order on the basis of Section 72 of the Ley Municipal of 1876 and under the utility of:

«[...] properly established surveillance in brothels, unhealthy locales and insalubrious rooms and in other branches of hygiene that have such a strong influence on public health can prevent the development of contagious diseases and even epidemics» (Our translation).

This Real Orden may be considered the starting point of the tacit integration of prostitution hygiene into the nineteenth-century municipal hygiene project in Spain. It would become just one more component of epidemic prevention, which is why it would no longer be exclusively limited to public health, as was true until mid-century. Nevertheless, as mentioned, provincial capitals had already been organising and administrating this service by themselves for decades.

In a clear attempt by the Ministerio de la Gobernación to prevent the conflicts of authority that had been triggered by the municipal intention to organise the service, it reminded the Provincial Government that:

«The Governors, according to section 23 of the Provincial Law of 1882, are very especially obliged to oversee exact compliance with health and hy-

\footnotetext{
59. Guereña, n. 53, 1997, p. 37 (our translation).

60. Oficio del Ayuntamiento de Palma al Gobierno de la Provincia, 25/02/1882. Higiene de la Prostitución. Archivo Municipal de Palma, Fons Pons i Fàbregues, 1126/V. It reflects the Council's express intention to appeal the Provincial Government's annulment of the plenary agreement to organise prostitution hygiene.

61. Real Orden de enero de 1889 (our translation).
} 
giene laws, and take when needed, under their own responsibility, and with all urgency, the measures they deem convenient to preserve the public health from epidemics, contagious diseases, sources of infection and other similar risks, reporting to the Government; but these urgent measures, and only when necessary, do not include the power to administrate ordinary hygiene supervision, over which their only power is to strictly ensure that the town councils in charge thereof comply with the law» (our translation).

Thus, the Provincial Government maintained its pre-eminence in regulating extraordinary public health measures (preventing and combating epidemics) while municipal control of ordinary public health was reaffirmed. This point of conflict between municipal and provincial authorities in administrating this service was the common denominator prior to its municipalisation, and similar examples can be found in Madrid, Victoria, Granada ${ }^{62}$.

Despite the municipal intention to organise the service, the Palma Town Council did not formulate the Proyecto de Reglamento de Higiene de la Prostitución until the Real Orden mentioned above was issued in early February 1889. Therefore, it is not surprising that the Provincial Government drafted its second regulation on this service in 1885 .

\section{Municipal regulations of prostitutions in Palma (19th century)}

As one of the purposes of this paper is to describe municipal regulations, these provincial regulations will not be fully analysed, although they serve as a basis of comparison for analysing the only municipal regulations at our disposal, which date from 1889. The provincial regulations of the city of Mahon (1876), given its geographic proximity, were also used, and possible similarities with other Spanish regulations found in the literature on this process are not without value.

The 1889 municipal regulations on the prostitution hygiene service merely meant the adoption of the basic principles that governed these types of regulations all over Spain. Thus, they were based on the general definition that: 
«Prostitution was not only a matter of health, it was also a police matter. Defending health and public health was associated with defending public order, as prostitutes were considered a factor of permanent disorder in the eyes of police authorities» ${ }^{63}$.

At the same time, they made use of the almost-identical Reglamento de la Sección de Higiene del Gobierno Civil de las Baleares (1885). Apparently, these provincial regulations were the direct model to be followed. Both regulations basically were defining an administrative structure of management, sanitary and also economic. They established the type of brothel - the only legal model for the exercise of the prostitution - and the medical periodical examination of the prostitutes (see Table 1).

Table 1: Comparison between Provincial and Municipal Regulations

\begin{tabular}{|c|c|c|}
\hline & Provincial Regulations (1885) & Municipal Regulations (1889) \\
\hline Preliminaries & - & On Prostitution Hygiene \\
\hline Chapter 1 & $\begin{array}{l}\text { Functions of the service and ad- } \\
\text { ministrative structure. Registry } \\
\text { of brothels and prostitutes }\end{array}$ & Section Object \\
\hline Chapter 2 & Types of brothels & $\begin{array}{l}\text { “Tolerated” Brothels } \\
\text { Types of brothels }\end{array}$ \\
\hline Chapter 3 & $\begin{array}{l}\text { Health card } \\
\text { Registration }\end{array}$ & On Registration \\
\hline Chapter 4 & & $\begin{array}{c}\text { Obligations of registered } \\
\text { women }\end{array}$ \\
\hline Chapter 5 & Duties of the Medical Hygienist & $\begin{array}{c}\text { Medical examinations and } \\
\text { health measures }\end{array}$ \\
\hline Chapter 6 & Taxes & Registration rights \\
\hline $\begin{array}{l}\text { Additional } \\
\text { Sections }\end{array}$ & $\begin{array}{c}\text { The Regulation's entry into } \\
\text { effect }\end{array}$ & $\begin{array}{l}\text { Organising the Asylum-Hos- } \\
\text { pital would be the object of a } \\
\text { different regulation. }\end{array}$ \\
\hline
\end{tabular}

Source: Higiene de la Prostitución. Archivo Municipal de Palma, Fons Pons i Fàbregues, 1126/V. 
The service was to perform a twofold function: A) supervising and controlling sanitary conditions and B) maintaining public order. In this way, a medical examination service was made available to both prostitutes as well as legally recognised, «casas toleradas» («tolerated» brothels) ${ }^{64}$. Medical supervision was expanded to prevent the spread of contagious diseases, which meant reaffirming the provisions established in the Real Orden 04/01/1889, mentioned above. Therefore, prostitutes were the object of the supervision, a defining characteristic of the period in which prostitution was regulated, as large-scale health campaigns to prevent venereal diseases were not devised until the first half of the twentieth century. As «most hygienists in Spain [...] considered prostitution the repository of the disease $[. .]. »{ }^{65}$, municipal regulations interpreted this preventive function under the heading of Disponer todo lo posible para evitar los efectos de la prostitución (Doing everything posible to prevent the effects of prostitution) and Reprimir en lo posible la prostitución (Suppressing prostitution as far as possible) ${ }^{66}$.

The service was administrated by the Sección de Higiene de la Prostitución (Prostitution Hygiene Department), and although guidelines for its duties were set, the administrative corps was not established. The provincial regulations established that it was to be made up of «an official from the provincial government, a medical hygienist and two inspectors ${ }^{67}$. Nevertheless, the municipal regulations clearly set out the duties of the medical hygienist, which are described below. If these municipal regulations were drafted by a special commission constituted for that purpose, together with the Junta Municipal de Sanidad, it is understood that this department was administrated by one of its components. Thus, the medical component of this service would not only be represented in terms of the medical hygienist's supervision and examination.

Inaugurating the service involved creating new infrastructures, such as a surgery for medical examinations when they were not carried out in brothels, and a hygiene hospital-Asylum, to provide medical treatment for

64. Artículo I. Preliminares. Proyecto de Reglamento de la Higiene de la Prostitución. Asuntos referentes a la Higiene de la Prostitución. Archivo Municipal de Palma, Fons Pons i Fàbregues, 1554/XVIII.

65. Castejón Bolea, Ramón. Las enfermedades venéreas y la regulación de la sexualidad en la España contemporánea. Asclepio. 2004, 56 (2): 223-241 (p. 226).

66. Artículos II y III. Capítulo I: Objeto de la sección. Proyecto de Reglamento, n. 64.

67. Artículo II. Capítulo I. Proyecto de Reglamento, n. 64. 
prostitutes with venereal diseases. Unfortunately, it is not known whether these infrastructures were merely words on paper in the regulations or were actually established. Parallel to drafting the regulations, the Town Council attempted to open a small infirmary to treat venereal diseases in «public women» (sic), under the auspices of the religious congregation of the Siervas de Jesús, who had recently settled in the city ${ }^{68}$. The municipal proposal included organising a teaching centre and opening the infirmary in a building known as the Casa de la Crianza, a traditional confinement home for repented prostitutes. It should be assumed that this did not come to pass, as at the same time, the Town Council arranged for the admission of public women with venereal diseases ${ }^{69}$ with the Provincial Governor and the Governor with the General Hospital Administrator, as the medical hygienist was only entrusted with conducting medical examinations and could not provide the prostitutes with medical treatment.

In contrast to other regulations, the definition of prostitution or who was considered a prostitute was not the starting point. The provincial regulations of Mahon (1876) assumed that «all women who cohabitate for a price with men who solicit them are considered prostitutes» ${ }^{70}$, and does not mention the sale of their bodies expressly, as did the different regulations in the city of Madrid ${ }^{71}$. Only the physical characteristics that a woman had to possess to be registered as a prostitute were described: not showing characters of complete puberty and evident signs of defloration and a robust constitution. Thus, a determined age range for exercising prostitution was being determined, although in contrast to regulations in other cities, no minimum age was established; in the case of Malaga, it varied from between 16 and 23 years of age in the 1885 and 1906 regulations, respectively ${ }^{72}$. Another salient aspect in the regulations was that prostitutes had to enrol on the municipal census and were given individual health cards prepared by the medical hygienist, which recorded possible incidents noted in medical examinations.

68. Circular del Ayuntamiento de Palma al Obispo de Mallorca, 11/01/1889. Asuntos referentes a la Higiene de la Prostitución. Archivo Municipal de Palma, Fons Pons i Fàbregues, 1554/XVIII.

69. Circular, n. 68

70. Reglamento para la vigilancia y servicio sanitario de las prostitutas de Mahón, 1876. Biblioteca Lluis Alemany, Palma, X-3 (227)/17.

71. Guereña, 1997, n. 51, p. 71.

72. Delange, David. A. Reglamentación sanitaria sobre prostitución en Málaga durante la etapa restauradora. Jábega. 1999; 82: 25-33 (p. 29). 
The regulations established the classes and categories of prostitutes, which were determined by residence or not in a tolerated brothel. This type of brothel was legally recognised through the purchase of an operating licence. The location of authorised brothels (see Map 1) reveals that their territorial emplacement depends on their class; as a consequence first class brothels are best located in city centres than second class brothels. Probably this distribution was related to all taxes charged when opening the business along with the rental and purchase prices of buildings. On the other hand, first class brothels were also used for housing purposes. The territorial location of second-class brothels coincides with the present Palma's prostitution area; even though today's structural characteristics are totally different.

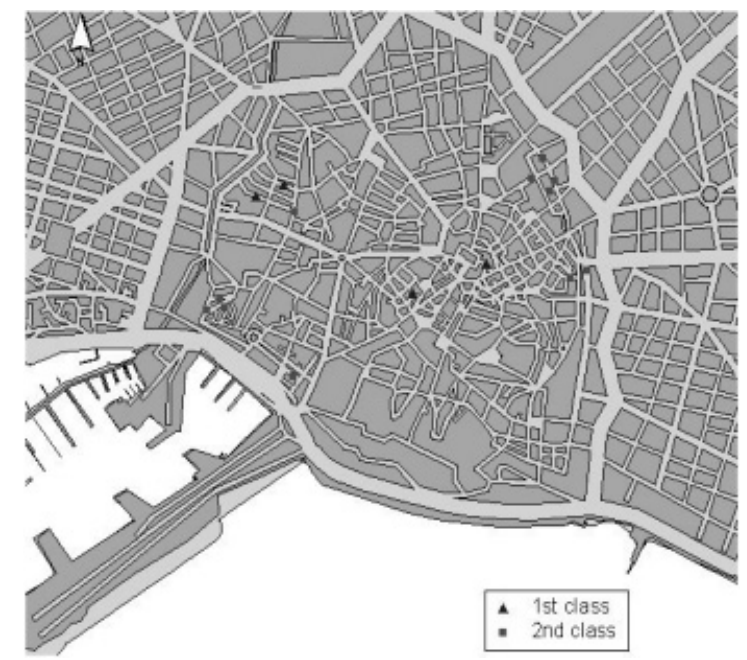

Source: Medical examinations of the prostitutes. Higiene de la Prostitución. Archivo Municipal de Palma, Fons Pons i Fàbregues, $1126 / \mathrm{V}$

\section{Final remarks}

Even the great amount of medical sources Revista Balear de Ciencias Médicas, minutes of the Real Academia de Medicina y Cirugía de las Islas Baleares (Royal Balearic Academy of Medicine), summaries of the historical studies of the Colegio Médico-Farmaceútico de Palma, the medical topography of 
Weyler and so on) highlight a lack of debate among the Majorcan medical profession over syphilis as a social matter because the only existing debate is from a medical point of view. Even though the Real Academia de Medicina y Cirugía de las Islas Baleares acted as consultative and facultative body in hygienic and epidemic matters (i.e., creating regulations of preventive measures and anti-epidemic fight during the cholera invasion of 1884), its minutes do not reveal any debate on Prostitution Hygienic Regulations. This fact confirms the hypothesis that such regulations have an economic character more than an hygienic character.

The municipal regulation of prostitution in the city of Palma was consistent with the common practice in Spain, although the central government did not establish a unitary model. Therefore, few aspects can be named as exclusive to the city, except perhaps the city's intention to establish a hospital for treating venereal diseases under the auspices of a religious congregation. 